УДК 338.48

\title{
АНАЛІЗ РОЗВИТКУ ДІЛЛОВОГО ТУРИЗМУ В ХАРКІВСЬКІЙ ОБЛАСТІ
}

\section{ANALYSIS OF DEVELOPMENT BUSINESS TOURISM IN KHARKIV REGION}

\author{
Радіонова Ольга Миколаївна \\ кандидат економічних наук, доцент, \\ Харківський національний університет міського господарства \\ імені О.М. Бекетова \\ ORCID: https://orcid.org/0000-0003-0570-3648 \\ Бражник Никита Олександрович \\ магістрант, \\ Харківський національний університет міського господарства \\ імені О.М. Бекетова \\ ORCID: https://orcid.org/0000-0003-4769-580X \\ Radionova Olha, Brazhnyk Nykyta \\ O.M. Beketov National University of Urban Economy in Kharkiv
}

\begin{abstract}
У статті проведено аналіз статистичних даних, що надає уявлення про стан та тенденції розвитку ділового туризму в Харківській області. Проаналізовано динаміку кількості туристів 3 діловою, службовою і навчальною метою. Визначено колективні засоби розміщення, що мають конференц-зали, які відповідають сучасним вимогам для проведення ділових заходів. Надано SWOT-аналіз сильних і слабких сторін для розвитку ділового туризму в Харківській області. Встановлено, що основними сильними сторонами області $є$ розвинений комплекс інфраструктурних об'єктів: колективні засоби розміщення, ресторани, парки, зони відпочинку, тощо; $€$ необхідний інструментарій для проведення виставок, семінарів, фестивалів для розвитку МІCE, ділового виду туризму. Слабкими сторонами є мала інорормованість про діловий туристичний ринок Харківського регіону; зношеність доріг; відсутність маркетингової кампанії турпродуктів Харківської області як на зовнішньому ринку так і на внутрішньому ринках.
\end{abstract}

Ключові слова: діловий туризм, Харківська область, розвиток, туризм, колективні засоби розміщення, конференц-зал, аналіз.

В статье проведен анализ статистических данных, который дает представление о состоянии и тенденциях развития делового туризма в Харьковской области. Проанализирована динамика количества туристов с деловой, служебной и учебной целью. Определены коллективные средства размещения, имеющие конфреренцзалы, которые отвечают современным требованиям для проведения деловых мероприятий. Представлен SWOT-анализ сильных и слабых сторон для развития делового туризма в Харьковской области. Установлено, что основными сильными сторонами области является развитый комплекс инфраструктурных объектов: коллективные средства размещения, рестораны, парки, зоны отдыха, и тому подобное; есть необходимый инструментарий для проведения выставок, семинаров, фестивалей для развития МІСЕ, делового вида туризма. Слабыми сторонами является недостаточная инорормированность о деловом туристическом рынке Харьковского региона; износ дорог; отсутствие маркетинговой кампании турпродуктов Харьковской области как на внешнем так и на врутреннем рынках.

Ключевые слова: деловой туризм, Харьковская область, развитие, туризм, коллективные средства размещения, консреренц-зал, анализ.

Despite the complex modern conditions for the development of tourism in general and the field of business tourism in particular, the role and importance of this area for the economy is important. Because the tourism industry allows you to effectively fill the budgets of cities, regions and, ultimately, the budget of the whole country. This industry attracts investment to the country, creates jobs in tourism, and in all related industries through the consumption of tourists a wide range of services and goods. The purpose of the article is to analyze the state and prospects of business tourism in the city of Kharkiv and the region. The article analyzes the statistical data, which provides an idea of 
the state and trends of business tourism in the Kharkiv region. The dynamics of the number of tourists for business, official and educational purposes is analyzed. Collective accommodation facilities with conference halls that meet modern requirements for business events have been identified. A SWOT-analysis of strengths and weaknesses for the development of business tourism in the Kharkiv region is provided. It is established that the main strengths of the region are the developed complex of infrastructural objects: collective means of accommodation, restaurants, parks, recreation areas, etc.; there are the necessary tools for exhibitions, seminars, festivals for the development of MICE, business tourism. Weaknesses are low awareness of the business tourism market of the Kharkiv region; road wear; lack of marketing campaign for tourist products of Kharkiv region both in the foreign market and in domestic markets. It is established that in the Kharkiv region there are opportunities for the development of business tourism, which is associated with the presence of business centers and administrative centers. The basis for the development of business tourism are international congresses, seminars, fairs, exhibitions, festivals and more. For further development of business tourism in the Kharkiv region it is necessary first of all to change the ratio of price and quality in the direction of reducing the cost component; expansion of the network of enterprises with the service of renting vehicles at affordable prices, in order to provide modern transport needs for business tourists.

Keywords: business tourism, Kharkiv region, development, tourism, collective development, conference hall, analysis.

Постановка проблеми. Незважаючи на труднощі та складні сучасні умови для розвитку туризму в цілому і галузі ділового туризму зокрема, роль і значення даної сфери для економіки є важливою. Оскільки туристична галузь дозволяє ефективно наповнювати бюджети міст, областей і, в кінцевому рахунку, бюджет всієї країни. Дана галузь привертає в країну інвестиції, створює робочі місця в сорері туризму, й у всіх суміжних галузях за рахунок споживання туристами досить широкого спектру послуг і товарів.

Аналіз останніх досліджень і публікацій. Розвитку ділового туризму присвячені наукові роботи таких вчених як: Музичка Є.О., Галасюк С.С., Цимбаліст О.Ю., Коваль О.А., Васьковська І.І., Петренко В.А., Семенов В.Ф., Фадєєва Г.І., Шикіна О.В., Гончаренко Я.Є., Ремігайло І.Ю. [1-6] та ін. Втім питання розвитку ділового туризму в Харківському регіоні досліджені не достатньо.

Метою статті $\epsilon$ аналіз стану та перспектив розвитку ділового туризму в м. Харкові та області.

Виклад основного матеріалу. Харківська область $€$ найбільшим регіоном на території України, яка володіє високим виробничим і соціальним потенціалом, а також високо потенційним рівнем розвитку інфрраструктури в Україні. У області $\epsilon$ сильні сторони для розвитку туристичної галузі, можливості фрормування перспективних видів туризму.

Рівень розвитку туристичного сектора міста найкраще характеризує аналіз показників динаміки кількості туристів (як внутрішніх, так і іноземних). За останні десять років в Харківській області більш активно розвивається виїзний туризм. Треба звернути увагу на той фракт, що в 2020 році статистика туристичних потоків сильно погіршилась через пандемію COVID-19.
Динаміка кількості туристів з ділової, службової і навчальною метою показала, що у 2018 р. їх кількість дорівнювала 133 осіб, у 2019 р. - 237, осіб, а у 2020 р. - 18 осіб [7].

Таблиця 1

Кількість туристів, обслугованих
туроператорами та турагентами, зі
службовою, діловою та навчальною метою
в Харківській області у 2018-2020 рр.
\begin{tabular}{|c|c|c|}
\hline Рік & $\begin{array}{c}\text { Обслуговано } \\
\text { всього } \\
\text { туристів }\end{array}$ & $\begin{array}{c}\text { Туристи зі } \\
\text { службовою, діловою } \\
\text { та навчальною } \\
\text { метою }\end{array}$ \\
\hline 2018 & 25070 & 133 \\
\hline 2019 & 33021 & 237 \\
\hline 2020 & 18164 & 18 \\
\hline
\end{tabular}

Діловий туризм дозволяє зняти таку гостру проблему, як сезонний фрактор в туризмі, оскільки пік ділової активності припадає на зиму і міжсезоння, тобто якраз на час «низького сезону». Для визначення можливостей есрективного позиціювання ділового туризму на ринку Харківської області, надаємо відповідний SWOT-аналіз можливостей і перспектив для розвитку даного виду туризму (табл. 2).

Розвиток ділового туризму неможливий без чітко-розвиненої інфрраструктури, а саме, дорожньої і готельної.

Динаміка кількості колективних засобів розміщення, за даними головного управління статистики Харківської області 3 2018 по 2020 роки, показала їх зменшення. У 2020 році кількість колективних засобів розміщування зменшилось на 1 од. по відношенню до 2018 року та на 7 од. по відношенню до 2019 року [7].

Для того, щоб залучати ділових туристів необхідний розвиток мереж виставкових кон- 


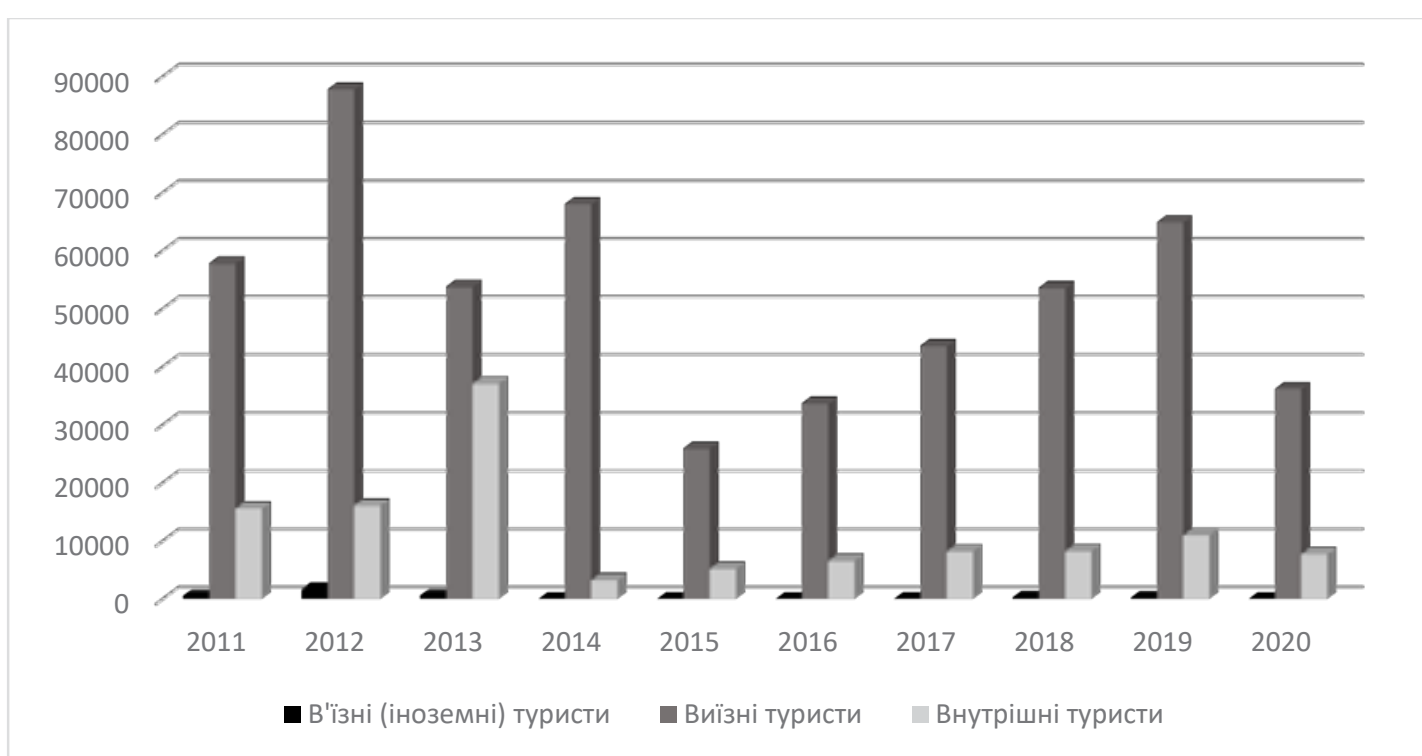

Рис. 1. Динаміки кількості туристів обслугованих туроператорами та турагентами за видами туризму в Харківській області у 2011-2020 рp.

Джерело: [7]

Таблиця 2

SWOT-аналіз сильних і слабких сторін для розвитку ділового туризму в Харківській області

\begin{tabular}{|c|c|}
\hline Сильні сторони (S) & Слабкі сторони (W) \\
\hline 1 & 2 \\
\hline \begin{tabular}{|l} 
Розвинений комплекс інфрраструктурних \\
об'єктів (колективних засобів розміщення, \\
ресторанів, парків, зон відпочинку та ін.)
\end{tabular} & Зношеність обласних і районних доріг \\
\hline $\begin{array}{l}€ \text { весь необхідний інструментарій для } \\
\text { проведення виставок, семінарів, відряджень } \\
\text { та різних фрестивалів для розвитку МІСЕ та } \\
\text { ділового виду туризму. }\end{array}$ & $\begin{array}{l}\text { Неінформованість та відсутня маркетингова } \\
\text { компанія турпродуктів Харківської області як } \\
\text { на зовнішньому ринку так і на внутрішньому. }\end{array}$ \\
\hline $\begin{array}{l}\text { Розвиненість Харківщини за багатьма } \\
\text { економіко-соціальними параметрами }\end{array}$ & $\begin{array}{l}\text { Мала поінфрормованість про } \\
\text { туристичний ринок даного рє }\end{array}$ \\
\hline \multirow[t]{3}{*}{\begin{tabular}{|l|} 
Присутність на території області різних \\
комерційних організацій, які можуть впливати \\
на рівень туризму.
\end{tabular}} & $\begin{array}{l}\text { Недостатній рівень конкурентоспроможності } \\
\text { місцевого розміщення. }\end{array}$ \\
\hline & $\begin{array}{l}\text { Не достатня кількість профресійних кадрів для } \\
\text { роботи у діловій сорері туризму, МІСЕ }\end{array}$ \\
\hline & $\begin{array}{l}\text { Відсутність політичної уваги і дер } \\
\text { політики з розвитку та підтримки I }\end{array}$ \\
\hline Можливості (O) & Загрози (T) \\
\hline $\begin{array}{l}\text { Великий обхват а також сфрера діяльності } \\
\text { реклами ділового туризму }\end{array}$ & $\begin{array}{l}\text { Невідповідність потребам ділової туристичної } \\
\text { сорери. }\end{array}$ \\
\hline $\begin{array}{l}\text { Велика увага та залучення інвестицій в місця } \\
\text { де буде поширений діловий туризм }\end{array}$ & $\begin{array}{l}\text { Територія області межує з областю, яка } \\
\text { непідконтрольна державі }\end{array}$ \\
\hline $\begin{array}{l}\text { Наявність туристичних та рекреаційних } \\
\text { ресурсів для розвитку туристичної та ділової } \\
\text { сорери області }\end{array}$ & $\begin{array}{l}\text { Низький рівень платоспроможності } \\
\text { населення через низькі доходи з основних } \\
\text { економічних галузей. }\end{array}$ \\
\hline \multirow[t]{2}{*}{$\begin{array}{l}\text { Відмінне географічне положення та наявність } \\
\text { міжнародного аеропорту }\end{array}$} & $\begin{array}{l}\text { Ігнорування цього виду туризму з боку } \\
\text { держави через відсутність виділення } \\
\text { бюджетних коштів на розвиток } \\
\end{array}$ \\
\hline & $\begin{array}{l}\text { Можливість наявності конкурентності між } \\
\text { українськими областями }\end{array}$ \\
\hline
\end{tabular}


Таблиця 3

Динаміка кількості колективних засобів розміщення у Харківській області

\begin{tabular}{|c|c|c|c|}
\hline Рік & $\begin{array}{c}\text { Кількість колективних } \\
\text { засобів розміщування, } \\
\text { од }\end{array}$ & $\begin{array}{c}\text { Кількість місць у } \\
\text { колективних засобах } \\
\text { розміщування, од }\end{array}$ & $\begin{array}{c}\text { Кількість осіб, що } \\
\text { перебували у колективних } \\
\text { засобах розміщування, осіб }\end{array}$ \\
\hline 2018 & 67 & 7511 & 218535 \\
\hline 2019 & 73 & 7824 & 187204 \\
\hline 2020 & 66 & 6698 & 80153 \\
\hline
\end{tabular}

грес-центрів, бізнес-готелів, платіжних систем, сучасних технологій, перш за все, інорормаційно-комунікаційних, щоб дозволити діловій людині незалежно від їі місця перебування управляти своїми справами. У м. Харкові та області відкрито понад 40 конференц-залів місткістю від 30 до 500 осіб, проте великих виставкових залів в місті небагато: ПВЦ «Радмір Експохол», Міська галерея, Палац Спорту. Однак велика кількість виставкових залів меншої місткості. Також функціонують кілька компаній, що займаються наданням меблів і обладнання для проведення консреренцій і переговорів а також ряд готелів.

В Харківської області $€$ досить комсрортні конфреренц-зали які створюють сприятливу атмосферу. Для кожного заходу необмежені можливості культурної програми. Є можливість організації невеликих перерв, кавабрейків, повноцінних сніданків, обідів і вечерь, виїзних заходів для багатоденних конореренцій і семінарів.

Приміщення в конфреренц-залах облаштовані клімат-контролем для забезпечення комфортних умов для всіх учасників. Якісне освітлення і звуковий супровід, мультимедійні установки для демонстрації презентацій, показу відеороликів або організації онлайн трансляцій сьогодні $€$ необхідним для організації сучасних бізнес-подій, і все це може забезпечити майже кожен конореренц-зал Харкова.

За даними аналізу на 2021 р. в Харкові існує 15 колективних засобів розміщення, які мають в наявності конференц-зали для ділових заходів, однак найбільш затребуваних п'ять. Докладний аналіз колективних засобів розміщення та окремих залів з метою з'ясування наявності: місць, кількості конфреренц-залів, необхідного обладнання для проведення ділових зустрічей і заходів надано у таблиці 4 [8].

Значної уваги при оренді конореренц-залу грає місце проведення бізнес-події в Харкові. Найчастіше це центр міста, бізнес-центри поблизу вокзалів і аеропортів. Для міжміських і міжнародних учасників за таких умов ідеально підходять готелі Харкова з конференц-залом. Організаторам простіше організовувати трансфер, перерви і час для відпочинку. Це в свою чергу означає, що під ці бізнес-події необхідно вибрати місце з конференц-залом, що знаходиться в легкій транспортної доступності.

Слід ще враховувати той фракт що, ділові туристи, можуть подорожувати разом зі своїми сім'ями. Ця тенденція веде до необхідності забезпечення в бізнес-готелях послуги няні та ігрових кімнат. Наприклад в багатьох країнах Європи і в США існують готелі і самостійні компанії, що займаються наданням послуг няні для бізнес-гостей. В Україні подібні послуги на даний момент розвинені не достатньо.

Найважливішим і ключовим фрактором для розвитку туристичної галузі $\epsilon$ і ії стан транспортних мереж. Харківська область відноситься до регіонів з розвинутим рівнем транспортної інфрраструктури, такі як залізничне, автомобільне і авіаційне сполучення. Харківська область посідає перше місце в Україні за протяжністю автомобільних доріг загального користування (близько 9,5 тис. км). Реконструкція і поява нових сучасних терміналів аеропорту яка відповідає європейським стандартам, створили додаткові умови для організації прямих рейсів. Що стосується бізнес авіації, в Харкові вона на етапі розвитку.

Висновки. На сьогодні, в м. Харкові та області $€$ можливості для розвитку ділового туризму, що пов'язано з наявністю бізнес-центрів і центрів адміністративного управління. Базою для розвитку ділового туризму $є$ міжнародні конгреси, семінари, ярмарки, виставки, орестивалі тощо. На думку різних експертів, місто та область цілком пристосовані для розвитку і підтримки ділового туризму.

Для подальшого розвитку сорери ділового туризму в Харківській області необхідно в першу чергу зміна співвідношення ціна та якість в сторону зменшення вартісної складової; розширення мережі підприємств 3 послугою прокату транспортних засобів за доступними цінами, з метою забезпечення сучасних транспортних потреб для бізнес-туристів. 
Аналіз кількості та оснащеності конференц-залів для проведення ділових заходів в Харківській області

\begin{tabular}{|c|c|c|c|c|c|c|c|c|c|c|}
\hline № & Об'єкт & 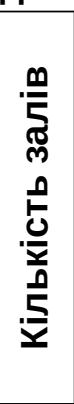 & 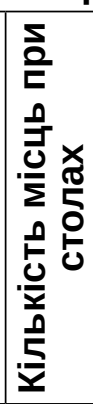 & 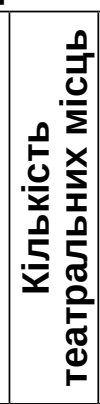 & 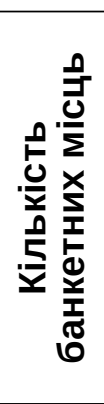 & 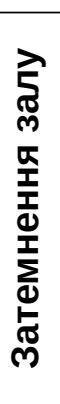 & 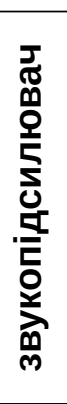 & 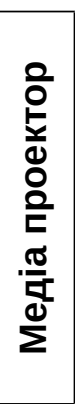 & 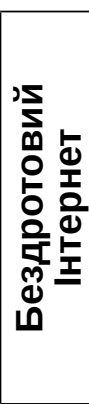 & 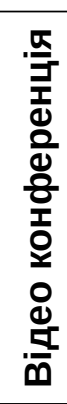 \\
\hline 1 & Готель «PARK HOTEL» 4 * & 2 & 16 & 50 & 0 & + & & + & + & \\
\hline 2 & Готель «KIROFF» 4* & 1 & 24 & 60 & 40 & + & + & + & + & + \\
\hline 3 & Освітній центр «я і Моя Школа» & 1 & 6 & 20 & 0 & + & + & + & + & + \\
\hline 4 & Навчальний центр «ПЛАНЕТА ЗН & 6 & 15 & 30 & 0 & & + & + & + & + \\
\hline 5 & Готель БРИТАНІЯ4 * & 7 & 400 & 650 & 1000 & + & + & + & + & \\
\hline 6 & Бізнес & 2 & 180 & 180 & 0 & + & + & + & + & \\
\hline 7 & Стадіон МЕТАЛІСТ & 4 & 100 & 270 & 180 & + & + & + & + & + \\
\hline 8 & «PREMIER HOTEL A & 3 & 100 & 180 & 132 & + & + & + & + & + \\
\hline 9 & ГОТЕЛЬ «ХАРКІВ» & 3 & 90 & 90 & 100 & + & + & + & + & + \\
\hline 10 & Єврейський культурн & 4 & 80 & 250 & 0 & + & + & + & + & \\
\hline 11 & Готель ГУБЕРНИЯ & 1 & 24 & 60 & 40 & & + & + & + & + \\
\hline 12 & $\begin{array}{l}\text { Готельно-ресторанни } \\
\text { «ДРУЖБА» }\end{array}$ & 2 & 50 & 350 & 300 & + & + & + & + & + \\
\hline 13 & Fabrikaspace & 5 & 30 & 450 & 30 & + & & + & + & + \\
\hline 14 & HOTEL 12 & 1 & 30 & 60 & 0 & + & + & + & + & + \\
\hline 15 & Конференц-зал «АЛІСА» & 1 & 24 & 100 & 24 & + & + & + & + & + \\
\hline
\end{tabular}

\section{СПИСОК ВИКОРИСТАНИХ ДЖЕРЕЛ:}

1. Музичка Є.О. Тенденції розвитку світового ринку MICE-туризму. Ефеективна економіка. 2019. № 2. URL: http://www.economy.nayka.com.ua/pdf/2_2019/60.pdf

2. Галасюк С.С., Цимбаліст О.Ю. Світові та національні тенденції розвитку ділового туризму. Світові тенденції та перспективи розвитку фрінансової системи : зб. матеріалів міжнар. наук.-практ. конфр., 15-16 грудня 2017 р. Дніпро : НО «Перспектива», 2017. Ч. 1. С. 9-12.

3. Коваль О.А. Васьковська І.І. Системний аналіз ділових послуг в Україні та аргументація створення бізнес-готелей в столиці. Intellectual potential of the XXI centuryurl. 2015. URL: http://www.sworld.com.ua/ konferm2/31.pdf

4. Музичка Є.О., Петренко В.А. Стан і тенденції розвитку ділового туризму в Україні. Економіка та держава. 2018. № 1/2018. C. 55-60. URL: http://www.economy.in.ua/pdf/1_2018/12.pdf

5. Семенов В.Ф., Фадєєва Г.І. Умови і сучасні тренди розвитку ділового туризму в Україні і світі. Регіональна економіка та управління. № 5(18). Запоріжжя, 2017. С. 149-156.

6. Шикіна О.В., Гончаренко Я.Є., Ремігайло І.Ю. Шляхи розвитку ділового туризму у період пандемії. Iнфрраструктура ринку. 2020. № 50. С. 213-219. URL: http://www.market-infr.od.ua/journals/2020/50_2020_ukr/37.pdf

7. Офріційний сайт Головного Управління статистики у Харківській області. URL: http://kh.ukrstat.gov.ua/

8. Конфреренц-сервіс в Україні. URL: https://conference-service.com.ua/confhall/search_res/region/22/

\section{REFERENCES:}

1. Muzichka, E. (2019) Tendentsii rozvitku svitovogo rinku MICE-turizmu. Efektivna ekonomika, no. 2. Available at: http://www.economy.nayka.com.ua/pdf/2_2019/60.pdf (in Ukrainian)

2. Galasyuk, S., Tsimbalist, O. (2017) Svitovi ta natsional'ni tendentsi] rozvitku dilovogo turizmu. Svitovi tendentsiï ta perspektivi rozvitku finansovoï sistemi: zb. materialiv mizhnar. nauk.-prakt. konf., 15-16 grudnya 2017 r. Dnipro: NO «Perspektiva», ch. 1, pp. 9-12. (in Ukrainian) 
3. Koval, O., Vaskovska, I. (2015) Sistemnii analiz dilovikh poslug v Ukraïni ta argumentatsiya stvorennya biznes-gotelei v stolitsi. Intellectual potential of the XXI centuryurl. Available at: http://www.sworld.com.ua/ konferm2/31.pdf (in Ukrainian)

4. Muzichka, E., Petrenko, V. (2018) Stan i tendentsii rozvitku dilovogo turizmu v Ukraini. Ekonomika ta derzhava, no. 1, pp. 55-60. Available at: http://www.economy.in.ua/pdf/1_2018/12.pdf (in Ukrainian)

5. Semenov, V., Fadeeva, G. (2017) Umovi i suchasni trendi rozvitku dilovogo turizmu v Ukraini i sviti. Regional'na ekonomika ta upravlinnya, no. 5(18). Zaporizhzhya, pp. 149-156. (in Ukrainian)

6. Shikina, O., Goncharenko, Ya., Remigailo, I. (2020) Shlyakhi rozvitku dilovogo turizmu u period pandemiï. Infrastruktura rinku, no. 50, pp. 213-219. Available at: http://www.market-infr.od.ua/journals/2020/50_2020_ukr/37.pdf (in Ukrainian)

7. Ofitsiinii sait Golovnogo Upravlinnya statistiki u Kharkivs'kii oblasti. Available at: http://kh.ukrstat.gov.ua/

8. Konferents-servis v Ukraini. Available at: https://conference-service.com.ua/confhall/search_res/region/22/ 